\title{
Een onvoorwaardelijk basisinkomen of een basisbaan?
}

\author{
Alfred Kleinknecht, Jos Kok, Ben Ligteringen, Joop Schippers \& Annelies van Egmond*
}

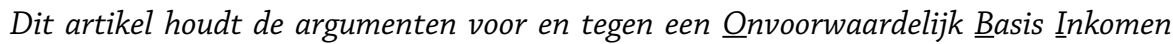
(OBI) van $€ 970$ voor iedereen boven de 18 jaar tegen het licht en raamt de tentatieve kosten. Na aftrek van besparingen op diverse uitkeringen die het OBI vervangt, blijkt dat er (netto) circa $€ 107$ miljard extra geld nodig is voor een OBI, hetgeen neerkomt op circa 43\% van de Rijksbegroting. Tevens komt een aantal serieuze ethische kwesties omtrent het OBI aan de orde. Alles afwegende komt dit artikel tot de conclusie dat ter bestrijding van structurele werkloosheid en armoede meer gerichte maatregelen de voorkeur verdienen boven een generieke maatregel als een OBI. Een interessante optie is in dit verband de eerdere suggestie van Muysken c.s. om uitkeringsgerechtigden recht te geven op een 'basisbaan' tegen het minimumloon, gefinancierd door de collectieve sector. Voor een veel lager bedrag dan de kosten van een OBI kunnen met basisbanen maatschappelijk zinvolle activiteiten worden verricht door mensen die op de reguliere arbeidsmarkt kansloos zijn.

\section{Inleiding}

Momenteel staat het onvoorwaardelijk basisinkomen weer volop in de belangstelling in het debat over sociale zekerheid en arbeidsmarktbeleid. Deze belangstelling wordt mede gestimuleerd door de in Nederland al meer dan dertig jaar actieve Vereniging Basisinkomen (http://basisinkomen.nl), die een platform geeft om een universeel en Onvoorwaardelijk Basis Inkomen (in het vervolg: OBI) te bepleiten. Bekende pleitbezorgers in de lage landen van een OBI zijn onder anderen Rutger Bregman (2014) en Philippe van Parijs (2016). De voorkeur voor een onvoorwaardelijk basisinkomen berust voor een belangrijk deel op de aanhoudend hoge werkloosheid en pessimistische verwachtingen daarover voor de toekomst. Maar er worden door pleitbezorgers ook andere argumenten genoemd, zoals meer persoonlijke autonomie en een sterkere positie van werknemers ten opzichte van werkgevers omdat men niet meer per se hoeft te werken om in

* Alfred Kleinknecht is emeritus hoogleraar economie van innovatie (www.alfredkleinknecht.nl) en verbonden aan de Hans-Böckler-Stiftung in Düsseldorf. Jos Kok is econometrist/macro-econoom met werkervaring bij het CPB, het ministerie van SZW en het Kenniscentrum van UWV. Ben Ligteringen is gepromoveerd op een historischsociologische analyse van het personeelsmanagement en was o.a. uitgever van vakbladen voor personeelsmanagement. Joop Schippers is hoogleraar arbeidseconomie aan de Universiteit Utrecht. Annelies van Egmond is econoom met werkervaring in het onderwijs, alsmede bij diverse bestuurs- en adviesorganen. 
een (minimaal) levensonderhoud te voorzien. Voorts worden als voordelen genoemd: rechtvaardigheid omdat ieder een gelijk bedrag ontvangt, alsmede minder bureaucratische regels en lagere uitvoeringskosten voor de sociale zekerheid.

In dit artikel onderwerpen wij de argumenten ten gunste van een basisinkomen aan een kritische evaluatie. We gaan na wat de mogelijke c.q. waarschijnlijke effecten van de invoering van een $\mathrm{OBI}$ zijn en geven een tentatieve raming van de kosten. Omdat er nogal wat haken en ogen aan een OBI blijken te kleven, schetsen we ter afsluiting van het artikel als alternatief de introductie van 'basisbanen' tegen het minimumloon voor uitkeringsontvangers. Deze lossen veel van de problemen op waar ook het OBI zich op richt, maar kennen niet een aantal van de daaraan verbonden nadelen.

\section{'AOW vanaf 18 jaar'}

Kort samengevat komt het OBI erop neer dat iedere inwoner van Nederland vanaf 18 jaar, zonder inkomens- of vermogenstoets en zonder sollicitatieplicht ('onvoorwaardelijk'), een netto-uitkering ontvangt ter hoogte van het bedrag van de bijstandsnorm voor alleenstaanden (op dit moment: $€ 973$ per maand). Dit komt dicht bij het bedrag van de AOW. Soms wordt het OBI dan ook aangeduid als 'AOW vanaf 18 jaar'. Het is overigens belangrijk om het OBI ('AOW vanaf 18 jaar') niet te verwarren met op handen zijnde beleidsexperimenten in diverse gemeenten om de regels voor het verkrijgen van bijstand te verzachten, dan wel geheel af te schaffen. Bijstand is een voorwaardelijk basisinkomen, in die zin dat men aan voorwaarden (zoals een inkomens- en vermogenstoets) moet voldoen om er recht op te hebben. Genoemde experimenten verdienen een aparte evaluatie. Dit artikel gaat uitsluitend over het OBI voor iedereen vanaf 18 jaar.

Een onvoorwaardelijk basisinkomen (OBI) betekent dat de band tussen werk en (basis)inkomen wordt doorgeknipt. Daarom moeten in een fundamenteel debat over het OBI niet alleen praktische zaken zoals kosten en verwachte gedragseffecten aan de orde komen, maar ook politiek-filosofische en ethische aspecten zoals de visie op mens en arbeid. Dan gaat het om de verantwoordelijkheden en vrijheden, rechten en plichten van individu en samenleving en om de relatie tussen inkomen en arbeid. Het gaat ook om visies op betaald versus onbetaald werk en over de vraag welk onbetaald werk eigenlijk betaald zou moeten worden. En ook om wat dit betekent voor de rol en verantwoordelijkheid van de overheid als hoeder van het algemeen belang. Deze onderwerpen komen hieronder aan de orde.

\section{Het OBI als spiegel van de visie op mens en maatschappij}

In onze samenleving doen verschillende visies de ronde op mens en maatschappij, met de daarbij behorende rechten, plichten en verantwoordelijkheden, alsmede 
op de relatie tussen arbeid en inkomen. In de literatuur worden veelal drie principiële visies onderscheiden (Esping-Andersen, 1990):

- Visie 1 - Het verzorgingsstaatmodel: Iedereen is in beginsel zelf verantwoordelijk om in zijn levensonderhoud te voorzien. Indien dat niet lukt door persoonlijke beperkingen of door omstandigheden, biedt de gemeenschap een helpende hand. De gemeenschap mag daar in redelijkheid wat voor terug vragen (bijv. sollicitatieplicht).

- Visie 2 - Het libertair-anarchistische model: Ieder individu is volledig voor zichzelf verantwoordelijk. Als dat niet lukt, dan heeft dat individu pech. Gelukkig is er nog de Caritas.

- Visie 3 - Het OBI-model: De gemeenschap is ervoor verantwoordelijk dat ieder (zonder tegenprestatie) een minimum krijgt voor zijn basisbehoeften, onafhankelijk van persoonlijke omstandigheden, inkomen of vermogen.

$\mathrm{Na} 1945$ is het verzorgingsstaatmodel in Europa stevig geworteld (EspingAndersen, 1990). Wel heeft het model vanaf het einde van de jaren zeventig onder invloed van het aanbodtheoretisch denken in de economie in nagenoeg alle landen een meer of minder sterke versobering ondergaan (Hemerijck, 2012). Het moge duidelijk zijn dat de keuze tussen de drie genoemde modellen van ieders individuele overtuigingen en mensbeeld afhangt. In hoeverre kent men gewicht toe aan solidariteit versus eigenbelang en aan collectieve versus individuele verantwoordelijkheid? Wie vertrouwt op goed werkende markten en wie neigt naar het denkbeeld van de rationeel handelende 'homo economicus', zal meer naar het libertaire model neigen. Wie overtuigd is van de feilbaarheid van markten en mensen en vertrouwt op de corrigerende en stimulerende mogelijkheden van de overheid, zal meer naar de klassieke verzorgingsstaat neigen. Men zou het OBI-model wellicht een gematigde tussenvariant kunnen noemen: het heeft anarchistisch-libertaire trekken door een (soms impliciet) wantrouwen in overheid en bureaucratie, en de nadruk op de 'autonomie' van het individu. Het model neigt echter wel naar de verzorgingsstaat met de nadruk op een basisinkomen als 'bodem' waaronder niemand mag zakken.

\section{Het belang van betaald werk}

Arbeid is voor velen niet meer uitsluitend de noodzakelijke 'labeur' om inkomen te vergaren (zie bijv. Mok, 1990). Het is steeds vaker ook identiteitsbepalend voor het individu. Het vergemakkelijkt sociaal contact, levert waardering op en draagt bij aan zelfrespect; het geeft sociale status en biedt de mogelijkheid voor zelfontplooiing. Aldus is werk een belangrijk middel voor sociale integratie en cohesie (o.a. Schippers, 2016).

De veronderstelling van veel pleiters voor een OBI dat mensen met een tot niets verplichtend OBI vanzelf wel iets gaan doen dat nuttig is voor de samenleving, is discutabel. Men zou - als men het methodologisch individualisme van de neoklassieke micro-economie loslaat - ook kunnen argumenteren dat de behoefte uit de samenleving leidend moet zijn voor wat 'nuttig' is en niet de individuele motivatie. Overigens is ook deze inschatting uiteraard afhankelijk van hoeveel 
waarde men hecht aan individualistische, dan wel collectivistische waarden (Hofstede \& Hofstede, 2007). Uiteindelijk is het ook weer een vraag van normen en waarden in hoeverre men informeel werk (zoals zorg voor kinderen) tot de normale sociale interacties rekent, dan wel dat men ervoor betaald moet worden. Men kan bijvoorbeeld tegenwerpen dat expliciete betaling van (grote) hoeveelheden van dergelijk informeel werk tot een te sterke 'financialisering' van de samenleving leidt (zie bijv. op het punt van mantelzorg Van Doorne-Huiskes et al., 2002; SCP, 2007).

\section{Argumenten voor een OBI en kanttekeningen daarbij}

Voorstanders van een OBI hebben daar uiteenlopende doelstellingen mee voor ogen (zie voor een overzicht Groot, 1999). De meest principiële voorstanders van een OBI zien het als een basisrecht van eenieder om zonder enige verplichting naar de gemeenschap toe van een bestaansminimum verzekerd te zijn. Dat maakt in hun ogen de mensen echt autonoom.

Anderen zien in de ongelijke rechten van de verschillende groepen werkzoekenden en de averechtse werking van veel bureaucratische regels binnen het socialezekerheidsstelsel een aanleiding voor een radicale vereenvoudiging door invoering van een OBI. Een basisinkomen zou ook de machtspositie van werknemers ten opzichte van werkgevers versterken. Immers de werknemer zit, als hij zich kan veroorloven genoegen te nemen met een bijstandsniveau van $€ 973$ per maand, niet meer aan een baan en een baas vast. Soms wordt ook beweerd dat het verstrekken van eenzelfde bedrag aan iedereen gewoon rechtvaardig is.

Voor veel voorstanders is een OBI van belang omdat het ook de mogelijkheid biedt om zich buiten de markt en het bedrijfsleven maatschappelijk verdienstelijk te maken. Het maakt mensen vrij om te kiezen wat ze willen doen. Het kan bijvoorbeeld studies of mantelzorg bevorderen.

Sommige voorstanders van een OBI noemen ook (te) hoge loonkosten voor bedrijven als argument ten gunste van een OBI. In sommige varianten van het OBI wordt dan het bedrag van $€ 973$ per maand als loonkostensubsidie aan de werkgever toegekend. Bij beëindiging van de arbeidsrelatie mag men de $€ 973$ meenemen om ervan te leven. Ter compensatie moeten de werkgevers dan wel hogere belastingen betalen. In sommige varianten richt men zich op grondstoffen (of op 'onttrokken waarde') of op toegevoegde waarde. Dit vereist een drastische belastingherziening, met een beoogde lastenverzwaring voor kapitaal- en grondstof-intensieve bedrijven ten gunste van arbeidsintensieve activiteiten.

Ten slotte leeft onder de aanhangers van een OBI ook de angst voor een 'arbeidsloze' samenleving in verband met de verspreiding van automatiseringstechnologie (zie bijv. de Second Machine Age-scenario's van Brynjolfsson \& McAffee, 2014).

Bij deze argumenten is een aantal kanttekeningen op zijn plaats.

Echte individuele autonomie bestaat niet. In een samenleving is men altijd van elkaar afhankelijk. Men wordt door een OBI niet echt 'autonoom', want men blijft ervan afhankelijk dat iemand anders belasting betaalt en dat anderen wel brood bakken, de vuilnis ophalen, spoorwegen aanleggen of voor drinkwater zorgen. Bovendien is (de hoogte van) het OBI afhankelijk van politieke machts- 
verhoudingen en gelegenheidscoalities. Men mag ook het belang van betaald werk, waarbij door het betaalelement expliciet de waardering voor werk als bijdrage aan de samenleving wordt uitgesproken, niet onderschatten. Ook is het dubieus om een gelijk bedrag voor iedereen als rechtvaardig te betitelen. Is het wel zo sociaal om ongelijke mensen strikt gelijk te behandelen?

Ten slotte, als men de regels binnen het socialezekerheidsstelsel onjuist vindt, dan moet men deze regels aanpassen. Daarom verdienen experimenten op het gebied van de bijstand een serieuze evaluatie. Maar dergelijke experimenten op het gebied van een voorwaardelijk basisinkomen kunnen niet worden beschouwd als een voorloper van een onvoorwaardelijk basisinkomen (zie box 1).

\section{Box 1: Over experimenten met een onvoorwaardelijk basisinkomen}

Nogal wat voorstanders van het OBI menen dat men de kosten en effecten van een onvoorwaardelijk basisinkomen kan afleiden uit experimenten met de bijstand (een voorwaardelijk basisinkomen). Zo worden experimenten op het gebied van de bijstand vaak als een experiment met het basisinkomen betiteld. Er zijn echter wezenlijke verschillen op cruciale aspecten van het aantal rechthebbenden, waardoor deze beperkte zeggingskracht hebben voor de mogelijkheden van een onvoorwaardelijk basisinkomen voor allen.

Experimenten met een echt OBI zijn zeer moeilijk uitvoerbaar. Überhaupt is men in Nederland ondanks de decentralisatietendensen die al tot verschillen in sociale voorzieningen tussen gemeenten leiden, vanwege de inherente rechtsongelijkheid nog steeds huiverig voor experimenten op het sociale terrein. Experimenten met een OBI creëren bovendien een ongelijk speelveld voor bedrijven. Bedrijven met werknemers (of zzp'ers) in de 'behandelde' groep krijgen dan namelijk door dit OBI een loonsubsidie (zie ook de volgende paragraaf) terwijl andere (namelijk die met werknemers en/of zzp'ers in de 'controlegroep') dat niet krijgen. Dat leidt bovendien tot extra ongelijkheid binnen een bedrijf dat werknemers heeft die woonachtig zijn in verschillende steden, waarvan sommige tot de experimentgroep en andere tot de controlegroep behoren. Het is juridisch en praktisch zeer lastig om dat op een eerlijke manier te corrigeren. Het veronderstelt ook dat cao-wetgeving lokaal buiten werking wordt gesteld.

Men kan ook argumenteren dat de maatschappij bereid moet zijn te betalen, als zij expliciet vraagt om zorg en andere maatschappelijk nuttige activiteiten die wezenlijk zijn voor het goed functioneren van de samenleving; dit in plaats van te hopen dat iemand deze activiteiten na invoering van een OBI wellicht vrijwillig oppakt. Voor een (betrouwbare) uitvoering van taken die de markt niet oppakt (of niet kan oppakken), moet de overheid haar verantwoordelijkheid nemen en mensen ervoor betalen. Als de betaling van een OBI niet aan te verrichten arbeid is gekoppeld, is de kans immers veel kleiner dat deze activiteiten (continu) worden verricht; men kan immers ook iets anders doen. Verderop in deze bijdrage pleiten wij daarom voor 'basisbanen'. 
Soms wordt het OBI ook beargumenteerd met de bewering dat we door robotisering en administratieve automatisering een tijd van hoge werkloosheid tegemoet gaan (zie o.a. Brynjolfsson \& McAffee, 2014). Echter, het is nog maar de vraag of hier doemverhalen op zijn plaats zijn. Er zijn ook economen die beweren dat er (op afzienbare tijd) geen hoge groei van de arbeidsproductiviteit meer is te verwachten, omdat technologische mogelijkheden (van bijvoorbeeld IT) uitgeput raken en omdat onder andere de toegenomen ongelijkheid de innovatie zal frustreren (Gordon, 2016). Bovendien zijn er sterke aanwijzingen dat 'structurele hervormingen' van arbeidsmarkten met een groeiende flexibiliteit van arbeid de innovatie en productiviteitsgroei ondermijnen (Vergeer \& Kleinknecht 2011, 2014). Door de zwakke loongroei en de lage groei van de arbeidsproductiviteit ontstaat dan juist een sterk arbeidsintensieve economische groei (Kleinknecht, 2015).

In historisch perspectief is er uiteraard regelmatig werk verdwenen, maar daar kwam meestal weer nieuw en ander werk voor in de plaats, waarbij overigens ook nog kortere arbeidstijden werden gerealiseerd. Wat er precies zal gebeuren, hangt ook af van hoe Nederland inspeelt op de technologische ontwikkeling. Transitie- en structuurproblemen zullen zich ongetwijfeld voordoen. Deze zullen naar verwachting vooral routinematige activiteiten raken (zie Van Est \& Kool, 2015). Vooral laag en verouderd opgeleiden zullen hieronder lijden. Daardoor zal waarschijnlijk - als er geen nader beleid wordt gevoerd - de nu reeds dreigende tweedeling tussen insiders en gemarginaliseerden groter worden, een tweedeling die juist door het basisinkomen als afkoopsysteem kan worden gevoed. Dreigende werkloosheid vraagt dus om andere maatregelen, zoals het voortdurend om- en bijscholen, het anders inrichten van (sommige) banen door 'jobcarving' alsook het creëren van genoemde basisbanen.

Overigens zijn de kosten van arbeid voor het exporterende Nederlandse bedrijfsleven geen probleem, zoals onder andere blijkt uit het structureel zeer hoge exportoverschot van Nederland. Het arbeidskostenprobleem kan wel aan de orde zijn bij laagproductieve banen aan de onderkant van de arbeidsmarkt. Voor dat probleem zijn echter meer gerichte maatregelen effectiever en efficiënter dan één grote, want breed gestrooide inkomensstroom in de vorm van een OBI.

\section{Effecten van een onvoorwaardelijk basisinkomen}

Voor een oordeel over de wenselijkheid van een OBI is het nodig ex ante een beeld van de waarschijnlijke effecten ervan te schetsen. Onderstaande lijst geeft hier een overzicht van. Het gaat om effecten die men op grond van inzicht in het gedrag van de diverse actoren, van kennis van de samenleving met haar instituties en wetten en op grond van onderzoeksresultaten met een grote mate van waarschijnlijkheid na invoering van een OBI kan verwachten. Deze zijn divers, en raken een veelheid van aspecten. Ze betreffen niet alleen de kosten en baten voor individu en gemeenschap, maar ook hun sociale, juridische en economische positie en verantwoordelijkheden. Dit gaat verder dan de direct beoogde doelstellingen die de voorstanders van een OBI voor ogen hebben, en bevat een aantal elementen die wij uit economisch en/of ethisch oogpunt als problematisch betitelen. 


\section{Algemene effecten}

- Iedereen krijgt onafhankelijk van zijn behoeften of noden eenzelfde voorziening. Dit roept een ethisch probleem op: is het wel zo eerlijk om ongelijke mensen gelijk te behandelen? Is het rechtvaardig om armen en rijken, gezonden en (chronisch) zieken, mensen met of zonder partner of (gehandicapte) kinderen exact hetzelfde OBI te geven?

- Het OBI versterkt de onderhandelingspositie op de arbeidsmarkt voor werknemers op of vlak boven het minimumloon, voor zover zij voornamelijk voor geld werken. Voor hogere inkomensgroepen heeft het veel minder effect. Hun onderhandelingspositie ten opzichte van de werkgever zal dus weinig veranderen. Per saldo kunnen er daardoor vooral aan de onderkant van de arbeidsmarkt veel vacatures openblijven, c.q. bestaat de mogelijkheid dat vooral laagbetaalden met minder leuke banen zich uit de arbeidsmarkt terugtrekken.

- Naarmate mensen zich na invoering van een OBI (gedeeltelijk) terugtrekken van de arbeidsmarkt, zullen de belastinginkomsten van het Rijk tegenvallen. Zo raamt het CPB (Jongen et al., 2015) bij een OBI van $50 \%$ van het netto sociaal minimum (ca. $€ 487$ per maand) een afname van het arbeidsaanbod met $5 \%$. Dit leidt tot een uitval van belastinginkomsten voor het Rijk van zeker $€ 7$ miljard. De auteurs verwachten dat vooral lager betaalde moeders met jonge kinderen relatief vaak zullen stoppen met werken (Jongen et al., 2015). Zo bezien zijn de effecten van het OBI vergelijkbaar met de traditionele 'aanrechtsubsidie'. Het lijkt erop dat ook voorstanders van het OBI dit beamen. Zo staat in de berekeningen van de Vereniging Basisinkomen dat de kinderopvangtoeslag kan vervallen omdat na invoering van het OBI ouders naar verwachting zelf meer op hun kinderen gaan passen (http://basisinkomen.nl/ het-basisinkomen-kan-kostenneutraal-worden-ingevoerd/). Uit onze zicht is dit echter minder positief: het kan de herintredersproblematiek vergroten en schaadt de emancipatie van de vrouw. Uit datzelfde CPB-onderzoek blijkt dat lage inkomensgroepen relatief sterk reageren op het verschil in inkomsten met en zonder werk, en zich bij een OBI dus sneller terugtrekken van de arbeidsmarkt. Hogere inkomens houden daarentegen een ruime financiële prikkel om te blijven werken. Overigens valt te verwachten dat bij een hoger OBI (bijvoorbeeld van $100 \%$ van het netto sociaal minimum, d.w.z. $€ 970$ p.m.) de door het $\mathrm{CPB}$ voorziene effecten veel groter zullen zijn. De OBIaanhangers hebben hier overigens wel een punt: voor zover door het OBI het arbeidsaanbod aan de onderkant verkrapt, kunnen de lonen van de laagbetaalden stijgen.

- Uitvoeringskosten van de sociale zekerheid kunnen bij een OBI omlaag. Het totaal van de uitvoeringskosten staat echter in geen vergelijking met het totaal der uitgaven voor sociale zekerheid. Bovendien kunnen als de bovenminimale uitkeringen van het UWV intact blijven, alleen de uitvoeringskosten voor het (minimum) inkomensdeel van de algemene bijstand door gemeenten, ad circa $€ 1$ miljard, en de uitvoeringskosten van de SVB voor de AOW en ANW van $€ 136$ miljoen vervallen. Daar staan wel uitvoeringskosten voor het OBI van ruim een half miljard tegenover, terwijl bovendien vanwege de inbouw van het $\mathrm{OBI}$ in de UWV-uitkeringen de complexiteit van de uitvoering, en 
dus ook de kosten daarvan nog verder zullen toenemen. Ergo is er sprake van een besparing van ten hoogste $€ 600$ miljoen. Als echter ook de bovenminimale uitkeringen van het UWV worden afgeschaft, kan er bij het UWV ook nog zo'n $€ 1,9$ miljard worden bespaard. Per saldo kunnen dan de besparingen op de uitvoeringskosten oplopen tot $€ 2,5$ miljard.

- Van het OBI gaat geen anticyclische werking uit wanneer, zoals door sommige voorstanders wordt bepleit, de bovenminimale WW-uitkeringen worden afgeschaft. De hoogte van het OBI is immers onafhankelijk van de stand van de conjunctuur. Met andere woorden, bij hoog- en laagconjunctuur wordt altijd hetzelfde bedrag uitgekeerd, waardoor conjunctuurschokken minder worden gedempt doordat er geen ingebouwde stabilisatoren van minder resp. meer WW-uitkeringen werkzaam zijn.

\section{Subsidies voor bepaalde groepen}

- Het is aannemelijk dat werkgevers zullen proberen de hoogte van het basisinkomen grotendeels te korten op de lonen, waardoor werknemers er netto niet of nauwelijks op vooruitgaan. Het netto-inkomen is immers vaak de focus bij loononderhandelingen. Mocht dit gebeuren, dan fungeert het OBI de facto als een subsidie voor werkgevers. Er zijn ook varianten waarbij het OBI direct als loonkostensubsidie aan de werkgever wordt uitgekeerd (die dan ter compensatie extra belastingen betaalt op grondstoffen en/of op toegevoegde waarde).

- In de praktijk zullen beroepsgroepen met een sterke positie op de arbeidsmarkt (zoals CEO's, advocaten, accountants) zich tegen deze korting op de lonen kunnen wapenen. Huishoudens met hogere inkomens kunnen er met andere woorden $€ 1945$ per maand (twee keer het basisinkomen) netto op vooruitgaan. Aan de onderkant van de markt zullen vermoedelijk zzp'ers met een magere opdrachtenportefeuille hun diensten tegen zeer lage tarieven willen en kunnen aanbieden, waardoor het OBI (gedeeltelijk) als subsidie voor hun opdrachtgevers functioneert.

- Door de lagere loonkosten kan een OBI wel extra werkgelegenheid opleveren, met name banen met een lagere productiviteit en matige betaling. Dit zal volgens studies van Vergeer en Kleinknecht (2011 en 2014) een verlaging van de groei van de arbeidsproductiviteit met zich meebrengen, aangezien lage loonkosten de invoering van arbeidsbesparende technologie vertragen. Een (nog) lagere groei van de Nederlandse arbeidsproductiviteit maakt de financiering van de vergrijzing (nog) lastiger. Immers, bij een groeiend aantal inactieven en een krimpende beroepsbevolking is een hogere groei van de toegevoegde waarde per arbeidsuur dringend gewenst (Storm \& Naastepad, 2008).

- Het OBI is ook een subsidie voor mensen die wel kunnen, maar niet willen werken. Er is immers nog steeds een groep die uit eigen beweging leeft op kosten van vermogen, bedrijf, het inkomen van een partner of van de ouders. Eind 2014 waren er ongeveer 1,6 miljoen mensen zonder baan of studie die ook geen werk zochten en geen uitkering ontvingen. Een basisinkomen voor deze groep verhoogt de collectieve lasten voor de samenleving met ongeveer $€ 18,7$ miljard, zonder dat de ontvanger het nodig heeft. 


\section{Effecten op de inkomensverdeling}

- Sommige voorstanders van een OBI willen dat alle socialezekerheidsuitkeringen worden vervangen door een basisinkomen. Dit kan een forse terugval betekenen voor 'bovenminimale' mensen die werkloos of (chronisch) ziek/arbeidsongeschikt worden. Iedereen valt immers direct terug op $€ 973$ per maand, onafhankelijk van het eerder verdiende inkomen.

- Als de huidige arbeidsongeschiktheidsregelingen worden vervangen door een OBI, zal in gevolge verdrag 121 van de ILO in Nederland een aparte sociale ongevallenverzekering moeten worden ingevoerd. Dit zal ook extra uitvoeringskosten met zich meebrengen. Nu wordt bij de arbeidsongeschiktheidsverzekering geen onderscheid gemaakt tussen het zogeheten risque professionnel en het risque social.

- Onder het OBI hebben huishoudens met meer personen boven de 18 jaar voordeel ten opzichte van het huidige bijstandsregime en AOW-stelsel. Daarentegen hebben alleenstaande ouders in de bijstand nu nog voordeel bij de alleenstaande-oudertoeslag ( $€$ 3.000), hetgeen onder een OBI vervalt. Algemeen geldt ook dat studenten erop vooruitgaan. Overigens speelt daarnaast nog de vraag of de extra uitkeringen van de bijzondere bijstand na invoering van een OBI blijven bestaan.

\section{Verantwoordelijkheden}

- Bij een OBI wordt impliciet verondersteld dat werkzoekenden zelf verantwoordelijk zijn voor het versterken van hun employability, het zoeken van werk of re-integratie. Er is veel minder morele druk voor overheid of werkgevers om zich hiervoor nog in te spannen.

- Een OBI geeft de overheid een legitimatie om haar verantwoordelijkheid voor het bevorderen van volledige (betaalde) werkgelegenheid te ontlopen. Ze kan ook doorgaan met het verschuiven van zorgtaken naar door het OBI gefinancierde mantelzorg. Het kan er zelfs toe leiden dat de overheid zich niet meer verantwoordelijk voelt aanpassingen aan werkplekken of extra ondersteuning te financieren om arbeidsgehandicapten in een betaalde baan te kunnen laten participeren.

- Ook geeft het OBI de werkgevers een moreel excuus om niet in te gaan op een beroep om laagproductieve of gehandicapte mensen in dienst te nemen. Immers, deze groepen hebben reeds een inkomen.

- Werknemers voor wie al jaren WW- en WIA-premie is betaald uit de loonruimte, hebben rechten opgebouwd op bovenminimale uitkeringen. Deze zijn door een betrouwbare overheid niet zomaar af te nemen. In het geval dat men ook de bovenminimale regelingen wil vervangen door een $\mathrm{OBI}$, is een uitfasering noodzakelijk. Dat eist een lange overgangsperiode, met hoge (bureaucratie)kosten en ook een lange tijd een tweedeling tussen mensen met de betere oude en mensen met de slechtere nieuwe regeling. 


\section{Solidariteit en draagvlak}

- Genoemde subsidies aan bedrijven en aan mensen die het niet nodig hebben, kunnen solidariteit en belastingmoraal doen eroderen, omdat men geen belasting of premie wenst te betalen voor een OBI voor mensen en/of werkgevers die het niet nodig hebben.

- De verlaagde participatie kan het maatschappelijke en het financiële draagvlak voor het OBI aantasten en vervolgens de hoogte ervan onder druk zetten. Het vergroot ook de tweedeling tussen degenen die erbij horen en de 'marginalen'.

- Door het genoemde afkoopkarakter kan een OBI grote groepen voor lange tijd buiten het arbeidsproces houden en tot een bestaansminimum van $€ 973$ veroordelen, met een verscherpte tweedeling (en afnemende sociale cohesie) van de samenleving tot gevolg.

- Aangezien veel OBI-aanhangers het OBI met hogere belastingen op Toegevoegde Waarde en op grondstoffen willen financieren, zal de inkomensongelijkheid voelbaar toenemen. Deze belastingen staan immers bekend als regressieve (= denivellerende) belastingen die de lagere inkomens harder treffen dan de hogere (Musgrave \& Musgrave, 1989).

\section{Kosten van een onvoorwaardelijk basisinkomen (zie box 2)}

Bij het huidige niveau van de bijstand ( $€ 11670$ per jaar voor een alleenstaande) zal een OBI voor alle ruim 13,5 miljoen Nederlanders boven de 18 jaar $€ 158$ miljard per jaar kosten. Daar komen nog uitverdieneffecten bij. Omdat het CPB bij een maandelijks basisinkomen van $€ 486$ de arbeidsparticipatie $5 \%$ lager en de arbeidsproductiviteit $1 \%$ hoger schat, rekenen wij hier voor een OBI van $€$ 972 optimistisch met uitverdieneffecten van slechts $€ 12$ miljard; dat kan zeer wel hoger uitvallen. De totale bruto kosten van een OBI moeten dan op minstens circa $€ 170$ miljard per jaar geraamd worden. Daar kunnen besparingen (van uitgaven voor doeleinden die min of meer met een OBI worden gedekt) tegenover staan. Omdat hieronder ook uitkeringen in verband met werkloosheid (WW en bijstand) worden gerekend, speelt ook de conjunctuur een rol in dit bedrag. Het gaat daarom ook meer om de orde van grootte dan om het exacte bedrag.

In box 2 zijn de netto jaarlijkse kosten (na aftrek van besparingseffecten) van een OBI op $€ 107$ miljard geraamd, hetgeen overigens dicht in de buurt komt van schattingen van de Vereniging Basisinkomen van $€ 104$ miljard (http:// basisinkomen.nl). Dit komt neer op $42 \%$, c.q. $43 \%$ van de totale collectieve rijksinkomsten van circa $€ 250$ miljard in 2016 (en collectieve uitgaven in dezelfde orde van grootte). Invoering van een OBI vergt dus een aanzienlijke verhoging van de collectieve lastendruk en/of drastische bezuinigingen op collectieve uitgaven (bovenop de in de tabel genoemde besparingsmogelijkheden).

$\mathrm{Na}$ de bezuinigings- en ombuigingsoperaties van de laatste jaren zullen verdergaande substantiële bezuinigingen op collectieve uitgaven alleen nog mogelijk zijn met zeer ingrijpende gevolgen voor publieke voorzieningen. Daarvoor zal vermoedelijk weinig politiek draagvlak bestaan. Het is dus aannemelijk dat het 
leeuwendeel van de vereiste $€ 107$ miljard extra financiële ruimte uit belastingverhogingen moet komen.

Het is niet moeilijk om te voorspellen dat bij verhoging van de belastingdruk met ruim $40 \%$ een forse (extra) prikkel ontstaat voor belastingontwijking. Schattingen van mogelijke fiscale tegenvallers als gevolg van (extra) belastingvlucht na invoering van een OBI zijn overigens in de berekeningen van box 2 niet opgenomen. De ervaring leert dat kapitaal zich makkelijker aan belastingheffing onttrekt dan arbeid. Ook rijke families zullen vermoedelijk door belastingvlucht of -ontwijking de lastenverzwaring ten minste voor een deel weten te ontlopen. Het lijkt dus realistisch om te verwachten dat de vereiste meeropbrengsten voor het Rijk extra zwaar op de lage en middeninkomens en de fiscaal minder uitgekookte bedrijven zullen gaan drukken.

Voor zover men van plan is de extra financieringsbehoefte voor het OBI via een hogere BTW en extra grondstoffenheffingen (zie http://basisinkomen.nl) te dekken, moet worden opgemerkt dat het hier om regressieve belastingen gaat die de lagere inkomens harder treffen dan de hogere inkomens. Immers, bij een BTW- of grondstoffenheffing kunnen (anders dan bij de inkomstenbelasting) geen progressieve tarieven voor grootverdieners worden ingebouwd. Bovendien is het aannemelijk dat het bedrijfsleven de hogere lasten gewoon doorberekent in de afzetprijzen. Aangezien hogere inkomens een groter deel van hun inkomsten kunnen sparen en over besparingen geen BTW- of grondstoffenbelasting geheven wordt, zullen de lagere en middeninkomens de lastenverzwaring relatief zwaarder voelen.

\section{Box 2: Raming kosten onvoorwaardelijk basisinkomen (OBI)}

Bron (voor zover niet anders aangegeven): begroting SZW 2016

Basisgegevens:

Hoogte bijstand $€ 972,70$ p.m. (incl. vakantietoelage) $\Rightarrow € 11.670$ p.j.

Bevolking 18+ per 1-1-2016: 13.563 .456 (Statistisch Jaarboek CBS)

Relevante volumes (uitkeringsjaren)

Wajong
WW
AO-wetten ${ }^{2}$
ZW/WAZO
WSW
Totaal

248.000 (tabel $4.2^{1}$ )

334.000 (tabel 3.5)

548.000 (tabel 3.4)

129.000 (tabel 6.5 en $6.7^{3}$ )

103.000 (tabel 2.10)

1.362 .000

Bijstandsniveau voor deze groep: $1.362 .000 \mathrm{x} € 11.670 \Rightarrow € 15,89$ miljard Kosten OBI: $€ 170$ miljard, namelijk: $13.563 .000 \mathrm{x} € 11.670=€ 158$ miljard plus uitverdieneffecten, te schatten op minimaal $€ 12$ miljard. 
Totale bruto kosten OBI (mld. €)

Min besparingseffecten:

waarvan:

AOW (incl. inkomensondersteuning)

ANW

Bijstand, TW en WSW

Deel minimum WW, ZW/WAZO, AO-wetten,

Wajong, WSW

Re-integratie-uitgaven

Uitvoeringskosten

Totale netto kosten OBI (mld. €):
170

63 Bron:

36 Tabel 8.2

$0,4 \quad$ Tabel 9.2

6,6 Tabel 2.1

16 Zie boven

3 Tabel 2.1.2.1

0,6 Zie hieronder

Ergo: boven op de huidige rijksinkomsten ( $€ 250$ mld.) moet er financieringsruimte van $€ 107$ miljard worden geschapen door óf de algemene belastingen met circa $43 \%$ te verhogen en/of op overheidsuitgaven te bezuinigen.

De uitvoeringskosten betreffen het inkomensdeel van de algemene bijstand ad $€ 1$ miljard $^{4}$ plus de AOW en ANW ad $€ 136$ miljoen; daar staan de uitvoeringskosten voor het OBI zelf van $€ 540$ miljoen tegenover, waarvoor de SVB kosten per klant ( $€ 40)$ worden verondersteld ${ }^{5}$.

Het gaat om de wetten:

ANW: Algemene nabestaandenwet (voor weduwen en wezen)

AO-wetten: alle arbeidsongeschiktheidswetten, de oude (WAO) en de nieuwe (WIA, WGA en IVA) d.w.z. Wet inkomensvoorziening arbeidsongeschikten, op te delen in Wet voor gedeeltelijk arbeidsongeschikten en de Inkomensvoorziening voor (geheel) arbeidsongeschikten. NB: de WAZ, Wet arbeidsongeschiktheidsverzekering zelfstandigen, bestaat m.i.v. 2014 niet meer; dus alleen oude gevallen

AOW: Algemene Ouderdomswet

TW: Toeslagenwet, waardoor iedere uitkeringsgerechtigde op het sociaal minimum kan komen

Wajong: arbeidsongeschiktheidswet voor mensen die van jongs af aan arbeidsongeschikt zijn

WAZO: Wet arbeid en zorg, waar o.a. zwangerschapsverlof uit wordt betaald WSW: Wet sociale werkvoorziening

WW: Werkloosheidswet

WWB: Wet werk en bijstand

ZW: Ziektewet voor mensen zonder vaste baan, zoals uitzend-, oproep- of invalkracht

\section{Noten:}

1 Alle hieronder genoemde tabellen komen uit de begroting SZW 2016).

216.000 oude WAZ-gevallen zijn niet meegenomen.

3 Het gaat om 143.000 mensen, die voor 16 weken bevallingsverlof krijgen +85.000 Uitkeringsjaren ZW. 
4 Geschat op basis van tabel 2.2. uitvoeringskosten inkomen uit CEBEONstudie uit 2010, zie http://www.cebeon.nl/wp-content/uploads/2015/05/ 5530-10-Uitvoeringskosten-gemeenten-en-UWV.pdf.

5 Zie jaarverslag SVB 2015.

We concluderen dat het vanwege de hoge bedragen aan bezuinigingen en/of lastenverzwaringen gaat om een fiscale mega-operatie die slechts kan werken in het geval dat een heel groot aantal landen meedoet. Een probleem in dit verband is ook dat - zoals vermeld - sommige aanhangers van een OBI een belangrijk deel van de financiering via grondstoffen- of toegevoegde-waarde-belastingen binnen willen halen. Wij signaleren in dit verband twee problemen.

Ten eerste zijn vanuit ecologisch oogpunt heffingen op grondstoffenverbruik zeer gewenst. Echter, het gaat hier wel om mega-bedragen, die Nederland en zelfs de Europese Unie niet geïsoleerd kan realiseren. De lobby van de grondstofintensieve industrie kan immers (geloofwaardig) dreigen haar activiteiten in Nederland of Europa te beëindigen en/of te verleggen naar landen zonder grondstoffenheffing. De dreiging dat bedrijven in bijvoorbeeld de staal- of chemische industrie tienduizenden arbeidsplaatsen opheffen, kan maatschappelijke weerstand oproepen, waardoor de politieke haalbaarheid van grondstoffenheffingen in het geding komt.

Ten tweede dient men zich te realiseren dat grondstoffenheffingen bedoeld zijn om een zuiniger gebruik van grondstoffen te stimuleren. Er doet zich dan het probleem voor dat naarmate de heffing succesvol is bij het behalen van haar ecologische doelstelling de belastingopbrengsten tegenvallen. Grondstoffenheffingen zijn dus geen solide basis voor een lange termijn financiering van een OBI.

\section{Alternatief: een basisbaan gefinancierd door de collectieve sector}

Het bovenstaande brengt ons tot de conclusie het OBI te ontraden. Het belangrijkste bezwaar is dat door een OBI in feite kansarmere groepen met geld worden afgekocht om niet te participeren in de samenleving. Het OBI kan dus onbedoeld de sociale uitsluiting bevorderen. Daarom bepleiten wij meer gerichte maatregelen. Indien de marktsector om welke redenen dan ook voor grote groepen geen werk biedt en sociale uitsluiting van niet-zo-nuttige mensen dreigt, dan ontstaat hier een taak voor de overheid als 'employer of last resort'. Ons pleidooi voor basisbanen knoopt aan bij eerdere suggesties van Mitchell en Muysken (2010) en Klosse en Muysken (2011), die voorstellen om langdurig werklozen en uitkeringsgerechtigden recht te geven op een baan (bij de gemeente) tegen het wettelijk minimumloon. Het minimumloon is een norm waarvan een politieke meerderheid in de Tweede Kamer vindt dat men er sober maar waardig van kan leven. Door consequent het minimumloon te betalen en door minder strenge eisen met betrekking tot de doorstroming naar de reguliere arbeidsmarkt op te leggen, onderscheiden deze basisbanen zich van de vroegere Melkert- en de ID-banen. 
Door strikt het minimumloon te betalen houden mensen een prikkel om werk in de marktsector te blijven zoeken, waar cao-lonen meestal boven het minimumloon liggen. Dit kan voor uitstroom uit de basisbanen zorgen, vooral in tijden van goede conjunctuur. We moeten ons echter geen illusies maken over de omvang van de uitstroom. Het gaat bij langdurig werklozen immers om de zwakste groep op de arbeidsmarkt. Voor menigeen zal een basisbaan de enige optie zijn om überhaupt nog te werken. Wel kan worden gesteld dat deze banen in het algemeen bijdragen aan het behouden en vergroten van de employability van betrokkenen. Bovendien is het raadzaam voor de sterkere werklozen de basisbaan te combineren met opleidingstrajecten, zodat het voor hen wel een opstapfunctie naar beter betaald werk in de marktsector kan zijn.

Gefinancierd door de publieke sector kan makkelijker dan in de marktsector voor zwakkere werklozen een beschutte werkomgeving worden aangeboden waar ze niet meteen de hoogste prestaties moeten leveren. Basisbanen zijn nieuwe (extra) ondersteunende banen (eventueel voor een deel gecreëerd door taakafsplitsingen) in bijvoorbeeld zorg, welzijn, natuur, cultuur, onderwijs of openbaar vervoer, gefinancierd door de overheid. Ze zijn bedoeld voor mensen die ondanks om-, her- en bijscholing en ondanks vele sollicitaties op eigen kracht geen plek op de arbeidsmarkt weten te bemachtigen. In een basisbaan leveren zij tegen het minimumloon conform hun productieve mogelijkheden een bijdrage om het zittende personeel te ontlasten en de dienstverlening te verbeteren. Onder deze extra banen kunnen ook onderdelen van maatschappelijk gericht vrijwilligerswerk worden gebracht. Deze worden dan teruggebracht als publieke taken, bijvoorbeeld onder de paraplu van de gemeente. Dit werk krijgt daardoor een betaalde status, waarin zich een concrete waardering van de maatschappij voor geleverd werk uitdrukt.

Voordeel voor betrokkenen is dat zij uit de complexe regelgeving rond de bijstand zijn verlost; ook dat ze gewone werknemers zijn, met alle rechten en plichten van dien. Behalve het te ontvangen minimumloon 'verdienen' deze werknemers met hun basisbaan zelfrespect, structuur in hun leven en sociale integratie. Door de inrichting van nieuwe taken en de inzet van meer personeel bij het bestaande kan de kwaliteit van de dienstverlening toenemen zoals die ervaren wordt door patiënten, leerlingen, reizigers en anderen. Gezien de activiteiten die door de basisbanen worden opgepakt, gaat het om economische groei in een arbeidsintensieve en grondstoffen-extensieve richting. Dit type economische groei houdt ook rekening met een breder begrip van welvaart, waarbij naast op de markt verhandelde goederen en diensten (gemeten als Nationaal Product) ook bijdragen aan 'zachte' factoren zoals cultuur, natuur, gezondheid of veiligheid meetellen in de welvaart (zie ook Stiglitz et al., 2009) en er niet als vrijwilligerswerk buiten vallen.

Een ander voordeel ten opzichte van het OBI is dat basisbanen niet prohibitief duur hoeven te zijn. Een grove raming moge illustreren in welke orde van grootte men moet denken. Bij deze raming veronderstellen wij dat de gemeente toch al de kosten van een bijstandsuitkering kwijt is; het gaat dus alleen om de extra kosten om het verschil tussen bijstand en minimumloon te overbruggen. Dit bedrag kan variëren, afhankelijk van persoonlijke omstandigheden. In de meeste gevallen komt dat bedrag op krap $€ 8.000$ per persoon per jaar. Nederland heeft nu circa 430.000 bijstandontvangers. Het ophogen van deze mensen naar het 
minimumloon kost: $430.000 \mathrm{x} € 8.000=€ 3.44$ miljard. Uiteraard komen daar nog overheadkosten bij voor administratie en inrichting van werkplekken. Niettemin is er geen sprake van exorbitante bedragen, zeker als men het vergelijkt met de kosten van een OBI (zie box 2). De kans is bovendien groot dat het maatschappelijk zelfs nog winst oplevert. Immers, zodra mensen in hun basisbaan waarde creëren die het verschil tussen bijstand en minimumloon (plus overhead) te boven gaat, is er sprake van maatschappelijke winst (t.o.v. het huidige bijstandsregime). Wel blijft de verdringing van reguliere banen door basisbanen een aandachtspunt. We moeten hier toezien op de integriteit van de uitvoerders van de regeling en vertrouwen op de waakzaamheid van democratisch gekozen organen zoals gemeenteraden die het geld verschaffen.

De introductie van basisbanen kan de sociale uitsluiting van kansarmere groepen tegengaan; men hoort er weer bij! Het voorkomt ook armoede en werkloosheid. Ten slotte heeft het idee van basisbanen het voordeel dat het politiek een stuk makkelijker is in te voeren dan het OBI. Ten eerste kost het maar een heel kleine fractie van de boven geraamde sommen van het OBI. Ten tweede is het in onze cultuur makkelijker uit te leggen dat mensen voor werk worden betaald dan dat men geld uitdeelt zonder enige tegenprestatie te eisen.

\section{Concluderende slotopmerkingen}

Voorstanders van een onvoorwaardelijk basisinkomen (OBI) noemen een aantal problemen die het OBI zou moeten oplossen. Wij argumenteerden dat een OBI bijna nooit de optimale oplossing is om het gestelde doel te bereiken. Ons inziens is een OBI een niet erg sociale maatregel, aangezien men ongelijke mensen (arm/ rijk, ziek/gezond enz.) strikt gelijk behandelt. Het is ook een vrij dure maatregel, die bovendien ongewenste effecten teweeg kan brengen. Zo is de kans groot dat het misbruikt wordt als afkoopregeling voor kansarme en niet-zo-nuttige werkzoekenden. Het kan de tweedeling vergroten tussen werkenden en 'marginalen'. Of het kan als 'aanrechtsubsidie' functioneren voor laagbetaalde vrouwen met minder leuk werk.

Voor zover men het OBI wil financieren via belastingen op toegevoegde waarde en grondstoffen, verscherpt dit bovendien (nog) verder de inkomensongelijkheid. Genoemde belastingen zijn immers 'regressieve' (denivellerende) belastingen die de ongelijkheid vergroten. Milieu- en grondstoffenbelastingen zijn ecologisch zeer gewenst. Echter, ze zijn geen solide basis voor een langdurige financiering van het OBI: naarmate de belastingen hun ecologische doelstelling bereiken (d.w.z. zuiniger gebruik), vallen de fiscale opbrengsten immers tegen.

Het OBI verschaft (loon)subsidies aan bedrijven en aan individuen die het niet nodig hebben, waardoor de solidariteit en de belastingmoraal verder onder druk komen te staan. Het OBI kan ook het (verder) terugtreden van de overheid legitimeren en geeft bedrijven moreel een excuus om niet in te gaan op een beroep om kansarmen of gehandicapten in dienst te nemen. Het OBI behandelt bovendien ongelijke mensen strikt gelijk en het is nog maar de vraag hoe ethisch dat is.

Voor het tegengaan van ongelijkheid is een basisbaan als gerichte maatregel veel goedkoper en effectiever. Bovendien zijn wij van mening dat het louter verstrek- 
ken van geld aan minder bedeelden via het OBI hun sociale uitsluiting niet voorkomt en hun ontplooiingsmogelijkheden remt. Het geld kan immers ook drank-, drugs- of gameverslaving subsidiëren. Voor veel minder geld dan voor een OBI kan de overheid bijstandsgerechtigden een basisbaan tegen het minimumloon aanbieden. Basisbanen kunnen de tweedeling in de samenleving tussen 'insiders' en 'outsiders' tegengaan. Ze voorzien ook in de maatschappelijke behoefte aan allerlei vormen van dienstverlening en ondersteuning door de inzet van mensen die in overgrote mate liever serieus en volwaardig meedoen dan aan de kant blijven staan. Ze vormen ook een betere garantie dat maatschappelijk nuttige activiteiten continu en betrouwbaar worden verricht dan erop te vertrouwen dat deze activiteiten na invoering van een OBI 'spontaan' door vrijwilligers worden opgepakt. Ten slotte mag worden opgemerkt dat dit concept er ook aan kan bijdragen dat de overheid haar grondwettelijke taak om te zorgen voor voldoende werkgelegenheid (art. 19.1 GW) inderdaad vervult.

\section{Literatuur}

Bregman, R. (2014). Gratis geld voor iedereen. Amsterdam: De Correspondent. Brynjolfsson, E. \& McAffee, A. (2014). The second machine age. New York: Norton. Cebeon (2010). Uitvoeringskosten gemeenten en UWV. Amsterdam (www.cebeon.nl).

Doorne-Huiskes, A. van, Dykstra, P.A., Nievers, E., Oppelaar, J. \& Schippers, J. (2002). Mantelzorg: tussen vraag en aanbod. Rapport nr. 63. Den Haag: Nederlands Interdisciplinair Demografisch Instituut.

Esping-Andersen, G. (1990). The three worlds of welfare capitalism. Cambridge: Polity Press.

Est, R. van \& Kool, L. (red.) (2015). Werken aan de robotsamenleving: Visies en inzichten uit de wetenschap over de relatie van technologie en werkgelegenheid. Den Haag: Rathenau Instituut.

Gordon, R (2016). The rise and fall of American growth. Princeton University Press.

Groot, L.F.M. (1999). Basic income and unemployment. Academisch proefschrift, Universiteit Utrecht.

Hemerijck, A. (2012). Changing welfare states. Oxford: Oxford University Press.

Jongen, E., Boer, H.-W. de \& Dekker, P. (2015). De effectiviteit van fiscaal participatiebeleid, CPB Policy Brief 2015-02, 14-2-2015.

Hofstede, G. \& Hofstede, G.J. (2007). Allemaal andersdenkenden: Omgaan met cultuurverschillen. Amsterdam/Antwerpen: Contact.

Kleinknecht, A. (2015). How 'structural reforms' of labour markets harm innovation. Research Paper No. 6. Online: http://www.socialeurope.eu/book/re-no-6-how-structural-reformsof-labour-markets-harm-innovation/

Klosse, S. \& Muysken, J. (2011). Overheid moet geen uitkering maar werk aanbieden. Me Judice, 02-11-2011.

Mitchell, W.F. \& Muysken, J. (2010). Full employment abandoned: Shifting sands and policy failures. International Journal of Public Policy, 5(4), 295-313.

Mok, A.L. (1990). In het zweet uws aanschijns ..., Leiden/Antwerpen: Stenfert Kroese.

Musgrave, R.A. \& Musgrave, P.B. (1989). Public finance in theory and practice. New York: McGraw-Hill.

Parijs, P. van (2016). Basic income and social democracy. Social Europe Journal. https:// www.socialeurope.eu/2016/04/44878/

Schippers, J. (2016). Werken is heel het leven niet. Kerk en Theologie, 67 (te verschijnen).

SCP (2007). Mantelzorg. Den Haag: Sociaal en Cultureel Planbureau.

Sen, A. (2009). The idea of justice. Harvard University Press \& Allen Lane. 
Stiglitz, J.E., Sen, A. \& Fitoussi, J.-P. (2009). The measurement of economic performance and social progress revisited. Paris: OFCE - Centre de recherche en économie de Sciences Po.

Storm, S.T.H. \& Naastepad, C.W.M. (2008). Wat de commissie Bakker weten moet. Economisch Statistische Berichten, 93(4534), 260-263.

Vergeer, R. \& Kleinknecht, A. (2011). The impact of labor market deregulation on productivity: A panel data analysis of 19 OECD countries (1960-2004). Journal of PostKeynesian Economics, 33(2), 369-404.

Vergeer, R. \& Kleinknecht, A. (2014). Does labor market deregulation reduce labor productivity growth? A panel data analysis of 20 OECD countries (1960-2004). International Labour Review, 153(3), 365-393. 